\title{
TENTANG KONSEP KEBUDAYAAN
}

\author{
Nurdien Harry Kistanto \\ Fakultas Ilmu Budaya Universitas Diponegoro
}

\begin{abstract}
Human consciousness towards the experience encouraged him composing formulation, definitions, and theories about the ways of his life, into the conception about culture. Consciousness thus commenced from the gift of reason, his human instincts and feelings, which are not owned by other beings, such as animals. Leslie White (1973), defined the conception of culture that includes "beliefs, ideologies, social organization, and technology (the use of tools)." In the second half of the 19th century Sir Edward Burnett Tylor, conducted a study of "primitive societies," which functions as the foundation for putting together the concept of culture: "Culture or Civilization ... is that complex which includes knowledge, belief, art, morals, law, custom, and many other capabilities and habits acquired by man as a member of society." Three quarters of a century later, Ralph Linton (1945), offers a formula about the culture that emphasized on the factor of integration achieved through a learning behavior: "A culture is the configuration of learned behavior and results of behavior whose component elements are shared and transmitted by the members of a particular society." While according to Koentjaraningrat (1974), elements of culture include (1) social organization systems; (2) systems of religion and religious ceremonies; (3) livelihood systems; (4) science and knowledge systems; (5) technology and equipment systems; (6) language systems; and (7) arts. Meanwhile, Anthony Giddens (1991), conceptualized culture by referring to the whole way of life of the members of a society. With the concepts of culture, background and multicultural experiences, in the communities of nation of Indonesia there can be arranged Indonesian socio-cultural systems.
\end{abstract}

Key Words: culture, concept, theory, elements.

\section{Pendahuluan}

Manusia dan kebudayaan tak terpisahkan, secara bersama-sama menyusun kehidupan.

Manusia menghimpun diri menjadi satuan sosial-budaya, menjadi masyarakat. Masyarakat manusia melahirkan, menciptakan, menumbuhkan, dan mengembangkan kebudayaan: tak ada manusia tanpa kebudayaan, dan sebaliknya tak ada kebudayaan tanpa manusia; tak ada masyarakat tanpa kebudayaan, tak ada kebudayaan tanpa masyarakat. Di antara mahluk- 
mahluk ciptaan Al-Khaliq, hanya masyarakat manusia yang meniru-niru Sang Pencipta Agung merekayasa kebudayaan. Kebudayaan adalah reka-cipta manusia dalam masyarakatnya.

Kesadaran manusia terhadap pengalamannya mendorongnya menyusun rumusan, batasan, definisi, dan teori tentang kegiatan-kegiatan hidupnya yang kemudian disebut kebudayaan, ke dalam konsepsi tentang kebudayaan. Kesadaran demikian bermula dari karunia akal, perasaan dan naluri kemanusiaannya, yang tidak dimiliki oleh mahluk lain, seperti hewan atau binatang. Dalam sementara pemahaman, secara biologis manusia pun digolongkan sebagai binatang, namun binatang berakal (reasoning animal).

\section{Binatang Berakal dan Binatang}

Binatang berakal sangat jauh berbeda dari binatang. Implikasi kepemilikan akal inilah yang jauh membedakannya dari binatang. Bagaimana dengan tingkah laku binatang yang berbeda dari Homo sapiens? Kenapa tingkah laku mereka tidak disebut kebudayaan? Semua binatang punya organisasi sosial, bahkan tanaman pun punya (Plant ecology: plant sociology). Binatang menggunakan peralatan, membuat rumah berupa sarang, yang dipelajari dan diwariskannya dari generasi sebelumnya. binatang juga memiliki pengetahuan dan konsepsi; kenapa tingkah laku mereka bukan produk kebudayaan? Karena tingkah laku, organisasi sosial species mereka ditentukan secara biologis, organisasi sosial mereka merupakan suatu fungsi dari struktur tubuhnya, fungsi dari komposisi genetiknya. Karakteristiknya antara lain, nonprogressive dan nonaccumulative. Karakteristik tingkah laku binatang adalah berdasarkan naluri alam, natural instinct, yang dibawanya sejak lahir hingga mati.

Sama-sama membutuhkan pakan dan papan, binatang tak menciptakan apa-apa berkaitan dengan kebutuhannya itu, kecuali berdasarkan nalurinya, atau mengembangkannya dengan sangat terbatas. Sejak burung pertama diciptakan, beterbangan mencari pakan dan 
membuat papan hingga sekarang, upaya dan buatan untuk memenuhi kebutuhannya tidak jauh berbeda; sejak dahulu sarang burung tetap seperti yang kita amati sekarang. Dapat dikatakan, kegiatan binatang semata-mata berbasis nature (alam) atau instinct (naluri), sedangkan kegiatan manusia berdasarkan akal, perasaan dan hatinya yang membentuk culture (budaya, kebudayaan).

Dalam species manusia, organisasi sosial bukan semata-mata fungsi struktur tubuh, melainkan fungsi suatu tradisi external suprabiological yang disebut "kebudayaan." Dalam jenis manusia terdapat macam-ragam organisasi sosial-budaya dan proses peralatan yang tak terhingga variasinya, yang bersifat progresif dan kumulatif, bersifat penyimbolan dan konseptual. Oleh sebab itu terdapat dua sosiologi yang secara mendasar membedakan antara organisasi sosial manusia dan organisasi sosial makhluk-makhluk lain, yakni (1) sosiologi species bukan-manusia (sociology of nonhuman species), yang merupakan subbagian dari biologi; dan (2) sosiologi manusia (sociology of human beings), yang merupakan subbagian dari ilmu kebudayaan, culturology, karena ia merupakan fungsi dari suprabiologikal eksternal, yaitu tradisi supraorganik yang disebut kebudayaan. Kemampuan berbicara pada manusia adalah karakteristik dari proses kebudayaan yang amat penting dan merupakan bentuk karakteristik dari penyimbolan (symboling). Dengan kemampuan tersebut manusia mengembangkan kebudayaan sehingga apa yang dihadapinya di dunia dapat diklasifikasikan, dikonseptualisasikan, diverbalisasikan. Dengan demikian pula hubungan-hubungan antar benda-benda disusun atas dasar konsepsi-konsepsi (White, 1979: 9-10).

Hubungan-hubungan biologis dan sekaligus sosial dipahami melalui ujaran artikulasi (articulate speech). Simpanse dan kera serta binatang-binatang lain punya ayah-ibu, pamanbibi, dan sebagainya, tapi mereka tidak mampu mengklasifikasikan semua hubungan- 
hubungan tersebut dengan ujaran artikulasi, yang bersamanya mengandung pula norma, etika, aturan, kebiasaan dan nilai-nilai (adat-istiadat). Dengan ujaran artikulasi, semua orang dengan siapa dia berhubungan sosial diklasifikasikan dan ditentukan; tugas dan kewajiban ditentukan untuk setiap kategori (White, 1979: 11).

\section{Konsep dan Unsur-Unsur Kebudayaan}

\section{1. Konsep}

Pada pertengahan kedua abad ke-19 Sir Edward Burnett Tylor (London, 2 Oktober 1832 - Wellington, 2 Januari 1917), Bapak Antropologi Budaya, Profesor Antropologi pada Universitas Oxford, Inggris, melakukan serangkaian studi tentang masyarakat-masyarakat “primitif”, yang meliputi perkembangan kebudayaan masyarakat manusia melampaui fase-fase transisi "from savage through barbaric to civilized life," dari masyarakat liar, melewati kehidupan barbarik sampai pada kehidupan beradab. Studi tentang kebudayaan masyarakat manusia ini disampaikannya dalam 2 (dua) jilid buku berjudul Primitive Culture setebal hampir 1000 halaman (Tylor, 1871), meliputi berbagai aspek kehidupan dan ketahanan hidup, kehidupan spiritual, kekuatan magik, sihir, astrologi, permainan anak-anak, peribahasa, sajak anak-anak, ketahanan adat, ritus pengorbanan, bahasa emosional dan imitatif, seni menghitung, berbagai macam dan ragam mitologi, hingga berbagai macam dan ragam animisme, ritus dan upacara.

Tylor (1871: 1) memanfaatkan studi ini antara lain sebagai landasan untuk menyusun konsep tentang kebudayaan, yang dirumuskannya secara singkat sebagai berikut.

Culture or Civilization... is that complex which includes knowledge, belief, art, morals, law, custom, and many other capabilities and habits acquired by man as a member of society.

(Kebudayaan atau Peradaban... adalah satuan kompleks yang meliputi ilmu pengetahuan, kepercayaan, kesenian, akhlak, hukum, adat, dan banyak kemampuan- 
kemampuan dan kebiasaan-kebiasaan lain yang diperoleh manusia sebagai anggota masyarakat).

Konsep awal kebudayaan yang bersumber dari studi tentang masyarakat-masyarakat primitif tersebut mengandung sisi praktis, sebagai sumber kekuatan yang dimaksudkan untuk mempengaruhi rangkaian gagasan-gagasan dan tindakan-tindakan moderen. Menyusun suatu hubungan antara apa yang manusia-manusia purbakala tak-berbudaya pikirkan dan lakukan, dan apa yang manusia-manusia moderen berbudaya pikirkan dan lakukan, bukanlah masalah ilmu pengetahuan teoretik yang tak-dapat-diterapkan, karena persoalan ini mengangkat masalah, seberapa jauh pandangan dan tingkah-laku moderen berdasarkan atas landasan kuat ilmu pengetahuan moderen yang paling masuk akal (Tylor, 1871: 443-44).

Lebih dari setengah abad kemudian, Ralph Linton (Philadelphia, Pennsylvania, 27 Februari 1893 - New Haven, Connecticut, 24 Desember 1953), Profesor Antropologi pada Universitas Columbia, New York, Amerika Serikat, menawarkan rumusan tentang kebudayaan yang menekankan pada faktor integrasi yang dicapai melalui tingkah laku belajar. Kebudayaan bisa dicapai dengan belajar dan sebagai hasil belajar yang dibiasakan antar anggota suatu masyarakat. Menurut Linton,

"A culture is the configuration of learned behavior and results of behavior whose component elements are shared and transmitted by the members of a particular society" (Linton, 1945).

(Kebudayaan merupakan konfigurasi dari tingkah laku yang dipelajari dan hasil tingkah laku yang unsur-unsurnya digunakan bersama-sama dan ditularkan oleh para warga masyarakat).

Pemahaman terhadap kebudayaan meliputi pengertian "sempit" dan "luas." Dalam pengertian "sempit," kebudayaan dipahami sebagai "kesenian," sehingga seniman dianggap sebagai budayawan, pementasan kesenian sering disebut sebagai acara budaya, misi kesenian yang melawat ke luar negeri sering dikatakan sebagai misi kebudayaan. Pandangan dan 
praktek demikian tentu mempersempit pengertian kebudayaan, terutama ditinjau dari unsur-

unsur atau isi kebudayaan sebagai strategi perluasan kebudayaan. Pengertian demikian tidak sepenuhnya keliru karena kesenian pun merupakan unsur kebudayaan yang penting. Sosiolog Inggris terkemuka, Anthony Giddens (1991) mengenai kebudayaan dalam hubungannya dengan masyarakat menerangkan sebagai berikut.

When we use the term in ordinary daily conversation, we often think of 'culture' as equivalent to the 'higher things of the mind' - art, literature, music and painting... the concept includes such activities, but also far more. Culture refers to the whole way of life of the members of a society. It includes how they dress, their marriage customs and family life, their patterns of work, religious ceremonies and leisure pursuits. It covers also the goods they create and which become meaningful for them - bows and arrows, ploughs, factories and machines, computers, books, dwellings (Giddens, 1991: 31-32).

(Ketika kita menggunakan istilah tersebut dalam percakapan biasa sehari-hari, kita sering berpikir tentang 'kebudayaan' sama dengan 'karya-karya akal yang lebih tinggi' - seni, sastra, musik dan lukisan.... konsepnya meliputi kegiatan-kegiatan tersebut, tapi juga jauh lebih banyak dari itu. Kebudayaan berkenaan dengan keseluruhan cara hidup anggota-anggota masyarakat. Kebudayaan meliputi bagaimana mereka berpakaian, adat kebiasaan perkawinan mereka dan kehidupan keluarga, pola-pola kerja mereka, upacara-upacara keagamaan dan pencarian kesenangan. Kebudayaan meliputi juga barang-barang yang mereka ciptakan dan yang bermakna bagi mereka - busur dan anak panah, bajak, pabrik dan mesin, komputer, buku, tempat kediaman).

\section{2. Unsur-unsur Kebudayaan}

Sementara ahli kebudayaan memandang kebudayaan sebagai suatu strategi (van Peursen, 1976: 10). Salah satu strategi adalah memperlakukan (kata/istilah) kebudayaan bukan sebagai "kata benda" melainkan "kata kerja." Kebudayaan bukan lagi semata-mata koleksi karya seni, buku-buku, alat-alat, atau museum, gedung, ruang, kantor, dan benda-benda lainnya. Kebudayaan terutama dihubungkan dengan kegiatan manusia (van Peursen, 1976: 11) yang bekerja, yang merasakan, memikirkan, memprakarsai dan menciptakan. Dalam pengertian demikian, kebudayaan dapat dipahami sebagai "hasil dari proses-proses rasa, karsa dan cipta manusia." Dengan begitu, "(manusia) berbudaya adalah (manusia yang) bekerja demi 
meningkatnya harkat dan martabat manusia. Strategi kebudayaan yang menyederhanakan praktek operasional kebudayaan dalam kehidupan sehari-hari dan kebijakan sosial dilakukan dengan menyusun secara konseptual unsur-unsur yang sekaligus merupakan isi kebudayaan.

Unsur-unsur kebudayaan tersebut bersifat universal, yakni terdapat dalam semua masyarakat di mana pun di dunia, baik masyarakat "primitif" (underdeveloped society) dan terpencil (isolated), masyarakat sederhana (less developed society) atau prapertanian (preagricultural society), maupun masyarakat berkembang (developing society) atau mengindustri (industrializing society) dan masyarakat maju (developed society) atau masyarakat industri (industrial society) dan pascaindustri (postindustrial society) yang sangat rumit dan canggih (highly complicated society). Unsur-unsur tersebut juga menunjukkan jenisjenis atau kategori-kategori kegiatan manusia untuk "mengisi" atau "mengerjakan," atau “menciptakan" kebudayaan sebagai tugas manusia diturunkan ke dunia sebagai "utusan" atau khalifah untuk mengelola dunia dan seisinya, memayu hayuning bawana - tidak hanya melestarikan isi alam semesta melainkan juga merawat, melestarikan dan membuatnya indah. Unsur-unsur kebudayaan tersebut dapat dirinci dan dipelajari dengan kategori-kategori subunsur dan sub-sub-unsur, yang saling berkaitan dalam suatu sistem budaya dan sistem social, yang meliputi (1) Sistem dan organisasi kemasyarakatan; (2) Sistem religi dan upacara keagamaan; (3) Sistem mata pencaharian; (4) Sistem (ilmu) pengetahuan; (5) Sistem teknologi dan peralatan; (6) Bahasa; dan (7) Kesenian (Koentjaraningrat, 1974).

\section{Sistem Sosial-Budaya Indonesia}

Para ahli kebudayaan memandang tidak mudah menentukan apa yang disebut kebudayaan Indonesia, antara lain dengan melihat kondisi masyarakat yang majemuk. Namun 
secara garis besar, setidak-tidaknya terdapat 3 (tiga) macam kebudayaan, atau sub-kebudayaan, dalam masyarakat Indonesia, yakni

(1) Kebudayaan Nasional Indonesia yang berlandaskan Pancasila dan UUD 45;

(2) Kebudayaan suku-suku bangsa;

(3) Kebudayaan umum lokal sebagai wadah yang mengakomodasi lestarinya perbedaan-perbedaan identitas suku bangsa serta masyarakat-masyarakat yang saling berbeda kebudayaannya yang hidup dalam satu wilayah, misalnya pasar atau kota (Melalatoa, 1997: 6).

Sementara itu, Harsya W. Bachtiar (1985: 1-17) menyebut berkembangnya 4 (empat) sistem budaya di Indonesia, yakni

(1) Sistem Budaya Etnik: bermacam-macam etnik yang masing-masing memiliki wilayah budaya (18 masyarakat etnik, atau lebih);

(2) Sistem Budaya Agama-agama Besar, yang bersumber dari praktek agamaagama Hindu, Budha, Islam, Kristen, dan Katolik;

(3) Sistem Budaya Indonesia: bahasa Indonesia (dari Melayu), nama Indonesia, Pancasila dan UUD-RI.

(4) Sistem Budaya Asing: budaya-budaya India, Belanda, Arab/Timur Tengah, Cina, Amerika, Jepang, dsb.

Selain itu, dapat ditambah "Sistem Budaya Campuran."

\section{Simpulan}

Dengan konsep-konsep tentang kebudayaan dan latar belakang dan pengalaman multietnik, multi-suku, atau secara keseluruhan, multi-budaya, memperhatikan gagasan-gagasan tentang sistem sosial-budaya (Melalatoa, 1997; Bachtiar, 1985), dalam masyarakat-bangsa Indonesia dapat tersusun sistem sosial-budaya nasional; sistem sosial-budaya suku bangsa dan 
etnik bangsa; sistem sosial-budaya agama; sistem sosial-budaya asing; dan sistem sosialbudaya campuran (Kistanto, 2008). Dari masyarakat-bangsa yang besar ini dapat disusun pula sistem-sistem sosial-budaya yang lain, seperti sistem sosial-budaya maritim; sistem sosialbudaya pertanian; sistem sosial-budaya industri dan pasca-industri; sistem sosial-budaya perkotaan dan sistem sosial-budaya pedesaan, dan sistem sosial-budaya adiluhung dan sistem sosial-budaya rakyat jelata, dan lain sebagainya.

\section{Daftar Pustaka}

Alexander, Paul. Ed. 1989. Creating Indonesian Cultures. Sydney: Oceania Publications.

Alfian. Ed. 1985. Persepsi Masyarakat tentang Kebudayaan. Jakarta: Gramedia.

Bachtiar, Harsya W., Mattulada, Haryati Soebadio. 1985. Budaya dan Manusia Indonesia. Yogyakarta: Hanindita. Company.

Benedict, Ruth. 1959. Patterns of Culture. Boston: Houghton Mifflin

Birket-Smith, Kaj. 1965. The Paths of Culture. Madison and Milwaukee: The University of Wisconsin Press.

Geertz, Clifford. 1960. 1976. The Religion of Java. Chicago and London: The University of Chicago Press.

1973. The Interpretation of Cultures. New York: Basic Books.

- 1983. Local Knowledge - Further Essays in Interpretive Anthropology. New York: Basic Books.

1995. After the Fact - Two Countries, Four Decades, One Anthropologist. Cambridge, Massachusetts: Harvard University Press.

Giddens, Anthony. 1989. 1991. Sociology. Cambridge, UK: Polity Press.

Jary, David \& Julia Jary. 1991. Collins Dictionary of Sociology. Glasgow: HarperCollins. 
Kistanto, Nurdien H. 2008. "Sistem Sosial-Budaya di Indonesia," Sabda Jurnal Kajian Kebudayaan, Volume 3, Nomor 1, April: 99-105.

Koentjaraningrat (Redaksi). 1971. 1993. Manusia dan Kebudayaan di Indonesia. Jakarta: Djambatan.

Gramedia. 1974. 1984a. Kebudayaan, Mentalitas dan Pembangunan. Jakarta: 1984b. Kebudayaan Jawa. Jakarta: Balai Pustaka.

Inc.

Linton, Ralph. 1936. The Study of Man. New York: Appleton-Century-Crofts, 1945. The Cultural Background of Personality. New York: D. Appleton-Century Company.

Malinowski, Bronislaw. 1960. A Scientific Theory of Culture and Other Essays. New York: Oxford University Press.

Melalatoa, M. Junus (Penyunting). 1997. Sistem Budaya Indonesia. Jakarta: FISIP UI \& PT Pamator.

Montagu, M. F. Ashley. Ed. 1968. Culture: Man's Adaptive Dimension. London: Oxford University Press.

Mulder, Niels. 1989. Individual and Society in Java - A Cultural Analysis. Yogyakarta: Gadjah Mada University Press.

Murphy, Robert F. 1979. An Overture to Social Anthropology. Englewood Cliffs, New Jersey: Prentice-Hall.

Pemberton, John. 1994. On the Subject of "Java." Ithaca and London: Cornell University Press.

Peursen, C. A. Van. 1976. Strategi Kebudayaan. Jakarta: BPK Gunung Mulia; Yogyakarta: Kanisius.

Quilici, Folco. 1972. 1975. Primitive Societies. London: Collins. New York: Franklin Watts.

Tylor, Edward Burnett. 1871. Primitive Culture. Vol. 1 \& Vol. 2. London: John Murray, 1920. 
White, Leslie A. with Beth Dillingham. 1973. The Concept of Culture. Minneapolis, Minnesota: Burgess. 